\title{
"We Were All Mixed Together": Race, Schooling, and the Legacy of Black Teachers in Buxton, 1900-1920
}

\author{
RICHARD M. BREAUX
}

IN MAY 1985, Iowa State University professor Janice Beran interviewed former Buxton resident Dorothy Neal Collier about blacks' and whites' experiences in that long-disappeared coalmining town. Collier was a child when the Consolidation Coal Company maintained the small town in south-central Iowa from 1900 to 1920. She had attended Fifth Street elementary school, one of the town's three racially integrated grade schools. After the Neals, like an increasing number of black families, left Buxton in 1916 for Cedar Rapids and other parts of Iowa and the Midwest, Dorothy, her brother Harry, and other black children like them began to notice that their educational experiences in Buxton had differed greatly from those in other towns in Iowa. Racial tensions and racial discrimination in education and employment were more obvious in towns elsewhere, and black teachers were extremely rare. ${ }^{1}$

1. Dorothy Collier, interview with Janice Beran, 6/19/1991, cited in Janice A. Beran, "Diamonds in Iowa: Blacks, Buxton, and Baseball," Journal of Negro History 75 (1992), 93. Here I focus primarily on schooling rather than education generally; hence, important institutions such as the church, home, and YMCA are discussed briefly and only in relation to the school.

I am grateful to Marvin Bergman, V. P. Franklin, Robert F. Jefferson, Christine A. Ogren, Katrina M. Sanders-Cassell, and four anonymous viewers for helpful comments and suggestions. Research for the article was supported by a 2004-2005 State Historical Society of Iowa Research Grant.

THE ANNALS OF IOWA 65 (Fall 2006). (C) The State Historical Society of Iowa, 2006. 
In interviews conducted in the 1980s, many former Buxton residents spoke of their lives and education in the context of their personal and collective experiences before, during, and after their time in Buxton. Always conscious of life for African Americans outside Buxton, both within and beyond Iowa's borders, African Americans from Buxton realized that although Buxton was not perfect in regards to race relations, it was indeed a utopia relative to places in other parts of the United States and places to which they later migrated. For example, former resident Charles Taylor remembered that his grandparents received the education in Buxton that they had been denied in Virginia. Taylor also pointed out that his grandparents had a difficult time adjusting to the racial climate in Buxton because in the South they did not believe that whites could be trusted. ${ }^{2}$ Another former Buxton resident recalled, "Buxton was a good place to live. ... They were good times. Then we moved to Des Moines and stepped back one hundred years." ${ }^{3}$ Former residents' statements contrasting Buxton with places with more tense racial conditions were not limited to working conditions; Dorothy Collier remembered of her school days in Buxton, "We were all mixed together. I couldn't understand the prejudice when we moved to Cedar Rapids when I was nine." ${ }^{4}$

2. Charles Taylor, interview with Dorothy and Elmer Schwieder, 7/8/1980; Dorothy Schwieder, Joseph Hraba, and Elmer Schwieder, Buxton: Work and Racial Equality in a Coal Mining Community (Ames, 1987). Schwieder, Hraba, and Schwieder offer some insights into education in Buxton, but they omit many of the details concerning education in Buxton from their monograph, although two-fifths of their interviewees at least mentioned schools and education. Those interviews and reports from the Bystander, Iowa's statewide African American newspaper, based in Des Moines, inform this article. All interviews, unless otherwise noted, refer to those conducted by Joseph Hraba or Dorothy and Elmer Schwieder. They are stored in audiotape and transcribed form in the Dorothy Schwieder Collection at the State Historical Society of Iowa, Des Moines. Interview page numbers refer to those designated when the transcribed interviews were catalogued.

3. Former resident quoted in David M. Gradwohl and Nancy M. Osborn, Exploring Buried Buxton: Archaeology of an Abandoned Iowa Coal Mining Town with a Large Black Population (Ames, 1990), 191.

4. Collier, interview. See also Vanessa Siddle Walker, Their Highest Potential: An African American School Community in the Segregated South (Chapel Hill, NC, 1996), 5-6, 224; and Faustine Childress Jones, A Traditional Model of Educational Excellence: Dunbar High School of Little Rock, Arkansas (Washington, DC, 1981), 3. 
At a time when Jim Crow reigned supreme in the North and the South, the residents of Buxton carved out a space for themselves where African Americans and European Americans worked side by side as laborers and professionals. In Buxton's schools, expressions of white supremacy and racial tension were relatively rare. Buxton was one of a few towns in Iowa that employed African American teachers in racially integrated schools before the 1940s, and it was possibly the only town to employ more than one African American teacher in its schools simultaneously. ${ }^{5}$ Buxton's schools and black teachers left the imprint on the minds of Buxtonites that blacks and whites could learn, work, play, and live together with little fear of racial hostility.

INTEGRATED SCHOOLS and the practice of welfare capitalism fostered the idea of Buxton as a racial utopia from the town's inception. In 1900 the Chicago and North Western Railroad moved its Consolidation Coal Company (CCC) from the town of Muchakinock, Iowa, in Mahaska County to Buxton in Monroe County. ${ }^{6}$ The town of Buxton was typical of many other coal-mining towns in that the CCC developed a paternalistic system of welfare capitalism. ${ }^{7}$ The CCC owned most of the property in the unincorporated town. Without incorporation, residents did not elect town officials. Elected county officials supervised those affairs that the CCC did not. For the town's first seven years, white Buxtonites barred blacks from the

For assessments of "good schools" among free blacks in the antebellum United States, see V. P. Franklin, Black Self-Determination: A Cultural History of AfricanAmerican Resistance, 2nd ed. (Brooklyn, 1992), 4. Sarah Lawrence Lightfoot also applied the model of the "good schools" to black and non-black schools in The Good High School: Portraits of Character and Culture (New York, 1983).

5. In 1911 C. W. Lewis, an African American graduate of Upper Iowa University, taught in a white school in Fayette County.

6. Hubert L. Olin, Coal Mining in Iowa (Des Moines, 1965), 44-45; Ronald L. Lewis, Black Coal Miners in America: Race, Class, and Community Conflict, 17801980 (Lexington, KY, 1987), 89.

7. Stuart D. Brandes, American Welfare Capitalism, 1880-1940 (Chicago, 1976), 5-6, 14-19; Schwieder, Hraba, and Schwieder, Buxton, 88-91; Joe William Trotter Jr., Coal, Class, and Color: Blacks in Southern West Virginia, 1915-32 (Urbana, IL, 1990), 3, 65; David Corbin, Life, Work, and Rebellion in the Coal Fields: The Southern West Virginia Miners, 1880-1922 (Urbana, IL, 1981), 117-18. 
town's ruling body, the Buxton Mining Colony. ${ }^{8}$ In 1907 an observer from the Southern Workman described Buxton as a place ruled paternalistically, but where blacks hoped to uplift themselves through education and work. ${ }^{9}$ Such paternalism within company towns was quite common. ${ }^{10}$ In the spirit of welfare capitalism, three schools, two YMCAs, a company store, shops, and a host of other institutions were developed to keep workers or their families from being idle for too long. Residents also established their own institutions, including churches, Masonic orders, local affiliates of the Iowa State Federation of Colored Women's Clubs, athletic teams, and musical organizations. ${ }^{11}$ The world that black and white Buxtonites and the CCC created functioned to prevent the racial friction that could result from labor shortages, segregated schools, and limited recreational facilities. $^{12}$

The opening of the Chicago and North Western Railroad's mines in Muchakinock (1881) and Buxton (1900) attracted many African Americans to south central Iowa. In Mahaska County, where Muchakinock was located, the number of African American residents quadrupled from 524 in 1880 to 2,138 in 1895. By 1905, approximately 600 more African Americans lived in Buxton than in all of Mahaska County a decade earlier; and at least 1,200 more African Americans lived in Monroe County than in Mahaska County at their respective peaks. Of Buxton's

8. The Buxton Mining Colony was originally for white employees only. Buxton Mining Colony, Constitution and By-Laws (Buxton, 1906), 1, State Historical Society of Iowa, Iowa City, Iowa. By 1908, the Mining Colony was open to black workers.

9. Richard R. Wright Jr., "The Economic Conditions of Negroes in the North," Southern Workman 37 (1908), 498; Gradwohl and Osborn, Exploring Buried Buxton, 22, 192.

10. Lewis, Black Coal Miners, xii-xiii; Trotter, Coal, Class, and Color, 15-17.

11. Bystander, 12/6/1907, 10/29/1909; Des Moines Register and Leader, 2/20/ 1910. The Bystander printed stories on Buxton almost on a weekly basis in a section called "Buxton, Iowa" or "Buxton Briefs."

12. The most complete account of life in Buxton is Schwieder, Hraba, and Schwieder, Buxton. They build on Olin, Coal Mining in Iowa; Stephen H. Rye, "Buxton: Black Metropolis of Iowa," Annals of Iowa 41 (1972), 939-57; Beverly Shiffer, "The Story of Buxton," Annals of Iowa 37 (1964), 339-47; and J. A. Swisher, "The Rise and Fall of Buxton," Palimpsest 26 (1945), 179-92. 


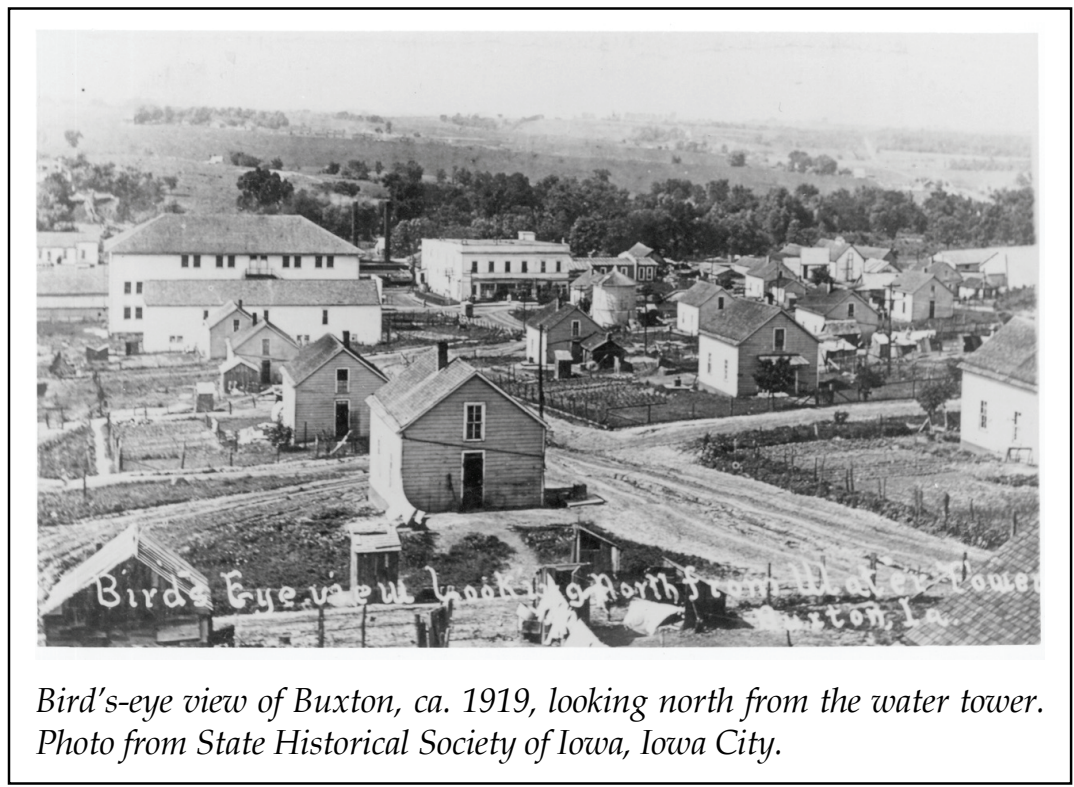

total population of 5,000 in 1905, 2,700 were black. ${ }^{13}$ The migration of African Americans to Buxton, like that to coal mines in West Virginia, "was neither rural to urban nor rural to rural, but rather rural to rural-industrial." ${ }^{14}$ African Americans who migrated to Buxton from states such as Virginia, Missouri, Alabama, and Tennessee often forged new class alliances that crossed racial lines and created an atmosphere based on racial cooperation and mutual respect.

Schools helped the children of African American migrants to Buxton make the transition from "peasants to proletariat." ${ }^{15}$ By

13. Census of Iowa, 1925, 718-21. Buxton's racial composition changed considerably over the years. In 1905 there were 2,707 blacks and 2,215 whites; in 1915 there were 1,818 blacks and 2,700 whites. Census of Iowa, 1905 and 1915, Manuscript Population Schedules for Bluff Creek Township, Monroe County.

14. Joe William Trotter Jr., "Race, Class, and Industrial Change: Black Migration to Southern West Virginia, 1915-1932," in Joe William Trotter Jr., ed., The Great Migration in Historical Perspective: New Dimensions of Race, Class, and Gender (Bloomington, IN, 1991), 46. See also Trotter, Coal, Class, and Color.

15. This phrase was taken from the title of a dissertation by Richard Walter Thomas, "From Peasant to Proletariat: The Formation and Organization of the Black Working Class in Detroit, 1915-1945" (Ph.D. diss., University of Michigan, 1976). See also Joe William Trotter Jr., "Introduction: Black Migration in 
the time of their migration, federal troops had been withdrawn from the South, planters had regained control of southern governments, and African Americans had lost substantial control of their rights to labor negotiation and education. As James Anderson points out, blacks lost economic and political power after Reconstruction, and in turn they "lost substantial control of southern educational institutions especially in the public sector, and the shape of their education took a different turn."16 Poor working conditions, the co-opting of southern education, the looming threat of white mob violence, and the purposeful diversion of financial resources away from black schools focused on classical training served as push factors in the trickle that later developed into a broad stream during the Great Migration of African Americans from the South to the North. ${ }^{17}$ Besides, southern whites' use of education as an instrument of racial, economic, and political subordination contradicted the liberation, social advancement, and self-determination blacks had sought for themselves. ${ }^{18}$ In the late nineteenth century and the first decade of the twentieth century, small rural northern towns such as Buxton offered African American children educational opportunities equal to that of whites rather than schooling that perpetuated racial hierarchies, with poor whites one stratum above all blacks regardless of class or education.

Historical Perspective: A Review of the Literature," in The Great Migration in Historical Perspective, 14.

16. James D. Anderson, The Education of Blacks in the South, 1860-1935 (Chapel Hill, NC, 1988), 3. For a general idea of the social and political climate in the South after Reconstruction, see C. Vann Woodward, The Strange Career of Jim Crow, 2nd ed. (New York, 1966), esp. 35-37, 44-45, 82-92.

17. Anderson, The Education of Blacks in the South, 152, 202-3, 260-61; Henry Allen Bullock, A History of Negro Education in the South, from 1619 to the Present (Cambridge, 1967), 208; Horace Mann Bond, Negro Education in Alabama: A Study in Cotton and Steel (New York, 1969), 234-37.

18. For more on blacks' desire for education during slavery and after emancipation, see Thomas L. Webber, Deep Like the Rivers: Education in the Slave Quarter Community, 1831-1865 (New York, 1978); Janet Duitsman Cornelius, "When I Can Read My Title Clear": Literacy, Slavery, and Religion in the Antebellum South (Columbia, SC, 1991); Bullock, "Introduction" in History of Negro Education in the South; Franklin, Black Self-Determination, 29-67; Anderson, Education of Blacks in the South, 4-5; and Linda Perkins, "Black Women and the Philosophy of 'Race Uplift' Prior to Emancipation,' in Filomina Chiema Steady, ed., The Black Woman Cross-Culturally (Cambridge, 1981), 317-34. 
As news from the North spread along African American kinship networks, the promise of equal educational opportunities became one of the reasons families with children came to Buxton. Extended black kinship networks, which included children too young to work in the mines, also played an important role in the CCC's decision to provide schools. ${ }^{19}$ Black men recruited to work for the company settled down and sent for their wives, sisters, mothers, and a host of other relatives to join them. Schools gave southern black parents incentive to migrate to communities where a formal education for their children might help break the cycle of sharecropping or the exploitation of child labor and convict leasing. The CCC might not have built permanent schools if such kinship networks, which included children, had not been in place. ${ }^{20}$ Schools reduced cases of truancy, imparted the company's unwritten policy of interracial cooperation, and kept children busy and out of trouble.

The state's elimination of racial segregation in its schools in the 1860s and 1870s was one of several reasons blacks came to Iowa and Buxton. African Americans in Buxton, like others in the coal mines of southern West Virginia, "faced fewer incidents of mob violence, fewer debilitating forms of labor exploitation, and, since they retained the franchise, fewer constraints on their exercise of political power" than blacks outside Iowa. ${ }^{21}$ The lives of African Americans in Buxton were different from those in southern coal mining communities in one major way-there was no state-mandated system of segregated education in Iowa.

By 1900, Iowa had long settled the debate over racially segregated schools, at least according to the letter of the law. ${ }^{22}$ In

19. For more on the development of kinship ties and the treatment of that subject in black migration historiography, see Joe William Trotter Jr., "Introduction," in The Great Migration in Historical Perspective, 13-15.

20. Census of Iowa, 1925, 718-21; James L. Hill, "Migration of Blacks to Iowa, 1820-1960," Journal of Negro History 66 (1981-82), 298-99.

21. Trotter, Coal, Class, and Color, 3.

22. The most comprehensive history of African American education in Iowa is Hal S. Chase, "'You Live What You Learn': The African American Presence in Iowa Education, 1839-2000," in Bill Silag et al., eds., Outside In: African American History in Iowa, 1838-2000 (Des Moines, 2001), 135-63. The most complete study of northern black education is Davison M. Douglas, Jim Crow Moves North: The Battle over Northern School Segregation, 1865-1954 (New York, 2005). 
terms of state laws and taxation, African Americans initially moved from invisibility to partial recognition within a Jim Crow school system. The connection between Jim Crow and Iowa schools arose as an issue of African American population density. In towns where there were one or two African American families among a community of whites, schools were desegregated quietly; in towns where the African American population was substantially larger, however, whites barred blacks from local schools and blacks established their own educational institutions. ${ }^{23}$ For example, African American parents established a school for black children in Dubuque in 1865. By 1867, African Americans in Keokuk and Muscatine operated grade schools for black children. ${ }^{24}$ The debate over segregated schools came to a head in Muscatine and Keokuk when African Americans sought to enroll their children in grades beyond those offered at African American schools. In 1868 the Iowa Supreme Court struck down racial segregation in a 2 to 1 decision; however, white Iowans challenged the constitutionality of desegregation twice more in the nineteenth century before the courts settled the debate. ${ }^{25}$ Some historians have celebrated these decisions as the end of school segregation in Iowa. Unfortunately, while black students could attend desegregated schools, whites

23. Arnie Cooper, "A Stony Road: Black Education in Iowa, 1838-1860," Annals of Iowa 48 (1986), 126-29. Cooper develops his thesis from earlier work by Clarence Aurner, History of Education in Iowa, 5 vols. (Iowa City, 1914), 2:375. Aurner claims that there were three phases to the racial desegregation of schools: 1) total exclusion and exemption from property tax; 2) limited school privileges in separate schools; and 3) equal school privileges.

24. Aurner, History of Education in Iowa, 1:91; Marilyn Jackson, "Alexander Clark: A Rediscovered Black Leader," The Iowan 23 (Spring 1975), 45-46.

25. Clark v. The Board of Directors, Etc., 24 IA 266 (June 1868). For other cases in which separate schools were ordered to desegregate after Clark, see Smith $v$. The Directors of the Independent School District of Keokuk, 40 IA 518 (June 1875); and Dove v. The Independent School District of Keokuk et al., 41 IA 689 (December 1875). The Original Minutes of the Independent School District of Mt. Pleasant from 1849 to 1876, from the Charles Rogers Estate, Mt. Pleasant, SHSI, Iowa City, IA, state that blacks had operated a school for children in Mount Pleasant, Iowa, since 1863. Schools there were desegregated in 1868. Such decisions only protected the rights of students. Except in Des Moines, Ottumwa, Buxton, and Fayette, African American teachers could not teach white children in the state until the 1940s. For more on the Oralabor school, see Chase, "You Live What You Learn," in Outside In, 147. 
in most Iowa towns barred African American teachers who had taught in all-black schools from teaching in desegregated schools. ${ }^{26}$

After legally sanctioned separate schools for African American children disappeared, race-based discriminatory residential patterns emerged in towns with relatively large African American populations. Des Moines, and later Waterloo, were the most obvious examples: most African Americans lived in the Center Street area of Des Moines and in Waterloo's East Side Triangle. ${ }^{27}$ Because children attended schools closest to their homes, residential segregation meant segregated schools. Despite its reputation, Buxton had its own race-based residential segregation. Shortly after the CCC established Buxton, two all-white suburbs, East and West Swedetown, developed on the outskirts of Buxton proper. Buxton's two predominantly black schools were in Buxton proper, and its predominantly white school was in East Swedetown. The racial demographics of Buxton's schools reflected the demographics of the adjoining neighborhoods.

Despite a steady increase of European immigrants in Buxton over the years, and the growing divide between African Americans and European Americans in social activities, two of Buxton's three schools remained mostly African American and all three were racially integrated. The number of African Americans enrolled in the Swedetown School cannot be determined, but its racial composition would have reflected the racial population of East Swedetown. Swedetown School was predominantly European American, but as one former student remembered, "there were some colored that went over there, the ones that lived" within short walking distance from the school. ${ }^{28}$ The composition of the two schools in Buxton proper appears to have been predominantly African American. A photograph of Minnie London's sixth grade class in 1907-08 shows 29 black

26. Leola Bergmann, The Negro in Iowa (1948; reprint, Iowa City, 1969), 87.

27. Charline J. Barnes and Floyd Bumpers, Iowa's Black Legacy (Charleston, SC, 2000), 109; and Philip G. Hubbard, My Iowa Journey: The Life Story of the University of Iowa's First African American Professor (Iowa City, 1999), 25-26.

28. Jacob Brown, interview with Joseph Hraba, 11/18/1980, 321 (also quoted in Schwieder, Hraba, and Schwieder, Buxton, 179); Sister Maurine Sofranko, interview with Dorothy and Elmer Schwieder, 9/28/1980, 990. 


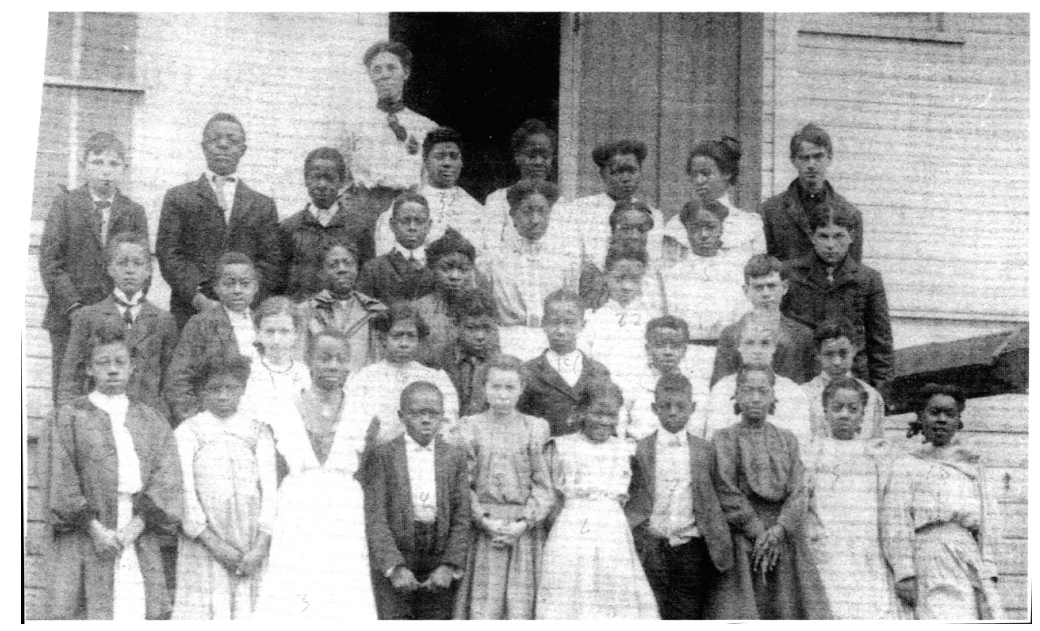

Minnie London's sixth-grade class in 1907, with 29 black students and 7 white students. Photo courtesy Kenneth R. Tow, Iowa Mines and Minerals Bureau.

and 7 white students. Dorothy Neal Collier's class picture, taken about 1912, at the Fifth Street Elementary School shows 48 blacks and 20 whites.

Although all three schools were racially integrated, two former students remembered that some whites in West Swedetown walked clear through Buxton proper to attend the school in East Swedetown. Some whites, to be sure, were afraid of blacks and chose to walk past Fifth or Eleventh Street schools to East Swedetown. ${ }^{29}$ At best, blacks and whites might have agreed that parents had the right to choose which school their child attended.

Furthermore, contrary to some informants' claims that the schools were completely integrated, several students and one teacher recalled that the Fifth and Eleventh Street schools employed all African American teachers and the Swedetown School employed all white teachers. Although African Ameri-

29. Charles Lenger, interview with Joseph Hraba, 7/22/1981, 532; Alex Erickson, interview with Dorothy and Elmer Schwieder, 8/15/1980, 1048; Earl Smith, interview with Joseph Hraba, 7/13/1981, 1119-20; Wilma Stewart, interview with Joseph Hraba, 7/21/1981, 172. 


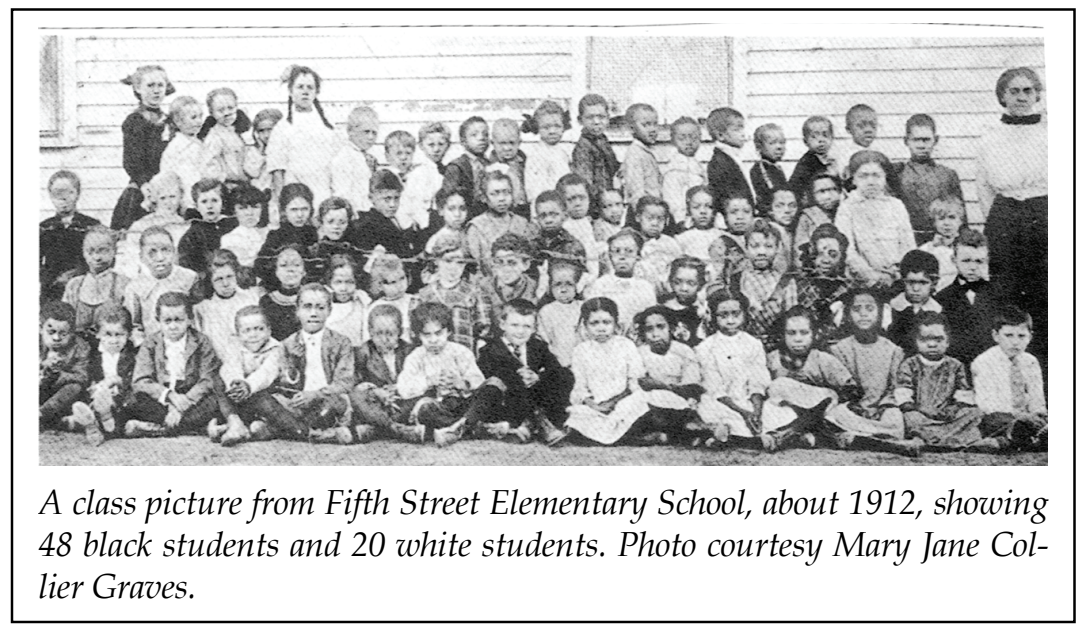

can teachers taught in racially integrated schools in Buxton, much of the evidence suggests that white teachers taught in the predominantly white school and black teachers taught in mostly black schools. ${ }^{30}$ Reports of black and white teachers in the same school were probably more the case with Fifth Street and Eleventh Street schools and not Swedetown.

Teachers in Buxton generally seem to have received equal salaries regardless of race, but there seem to have been exceptions. On average, public school teachers in Buxton made about $\$ 45$ per month, ranging from a low of $\$ 32.25$ per month in 1908 to a high of $\$ 70$ per month in $1920 .^{31}$

30. Lola Hart Reeves, interview with Dorothy and Elmer Schwieder, 6/21/1980, 1592. For student recollections of the racial composition of teachers, see Nellie King, interview with Joseph Hraba, 12/23/1980, 1060; Naomi Ambey, interview with Dorothy and Elmer Schwieder, 6/16/1981, 878; Earl Smith, interview, 1119. Helen Clay and Robert Wheels remembered having both white and black teachers. Helen Clay, interview with Joseph Hraba, 6/28/1981, 582; and Robert Wheels, interview with Dorothy and Elmer Schwieder, 6/8/1981, 390. This is confirmed in Dorothy Schwieder and Elmer Schwieder, "Sources for Social History: A Case Study of a Local Community," Annals of Iowa 49 (1988), 258.

31. Biennial Report of the Superintendent of Public Instruction (1914), 246-47; Schwieder, Hraba, and Schwieder, Buxton, 129-30. Compare Biennial Report of the Superintendent of Public Instruction (1906), 94-95; ibid. (1908), 286; ibid. (1910), 210-11; ibid. (1916), 164-65. On average, in 1914, white teachers in Buxton made \$37 more annually than black teachers. There was no similar equality in pay by gender. In all but one year, male teachers were paid between $\$ 18$ and $\$ 80$ more than female teachers. 
BUXTON SCHOOLS were somewhat of a northern anomaly and an anomaly among schools in other coal mining communities with regard to their treatment of African Americans; however, Buxton's schools shared characteristics of both northern urban and southern rural schools. ${ }^{32}$ Although most Iowa towns prohibited African American teachers from teaching in racially integrated schools, ample opportunities existed for African American women and men to teach in Buxton. African American teachers taught both white and black children and had little reason to protest racial injustice in the context of their immediate environment.

It is not clear whether people in Buxton favored completely racially segregated schools. The development of East and West Swedetown and the Swedetown School suggests a combination of prejudice and the desire to recreate an ethnic community among Buxton's newly arrived immigrant population. ${ }^{33}$ Some African Americans in northern cities openly opposed school desegregation because they feared that black teachers, whom school officials barred from teaching white children, would lose their teaching jobs. ${ }^{34}$ That is what happened even in Iowa,

32. In the past decade, there has been increasing interest in the history of black education in northern urban areas and in black life, including black education in northern rural and semi-industrial communities. See, for example, Jack Dougherty, More Than One Struggle: The Evolution of Black School Reform in Milwaukee (Chapel Hill, NC, 2004); Dionne A. Danns, Something Better for Our Children: Black Organizing in Chicago Public Schools, 1963-1971 (New York, 2003); Sundiata Keita Cha-Jua, America's First Black Town: Brooklyn, Illinois, 1830-1915 (Urbana, IL, 2000); Stephen A. Vincent, Southern Seed, Northern Soil: AfricanAmerican Farm Communities in the Midwest, 1765-1900 (Bloomington, IN, 1999); Don Wallis, All We Had Was Each Other: The Black Community of Madison, Indiana (Bloomington, IN, 1998); and Kenneth Marvin Hamilton, Black Towns and Profit: Promotion and Development in the Trans-Appalachian West, 1877-1915 (Urbana, IL, 1991).

33. The majority of Buxton residents were native-born. The foreign-born never accounted for more than 14 percent of the total population, although if secondgeneration immigrants are included, European immigrants accounted for nearly one-third of Buxton's population. The largest immigrant groups were Swedes (3 percent in 1905 and 1.9 percent in 1915) and Slovaks (2 percent in 1905 and 4.8 percent in 1915). See Census of Iowa, 1905 and 1915; and Schwieder, Hraba, and Schiweder, Buxton, 148-49, 162-68.

34. Judy Jolley Mohraz, The Separate Problem: Case Studies of Black Education in the North, 1900-1930 (Westport, CT, 1979), 101-2, 105; Carleton Mabee, Black Education in New York State: From Colonial to Modern Times (Syracuse, NY, 1979), 
where black teachers who had taught in all-black schools before 1875 could not find work in desegregated Iowa schools. Buxton's leaders, however, apparently recognized the value of African American teachers and administrators even in racially integrated schools. If they recognized it in principle, however, they did not always do so in practice. An editorial in the April 1905 Buxton Eagle pointed out that the CCC had "ruined the educational principle of the town by establishing and maintaining a separate white school and at the same time placing a white principal over the deserving and cultured colored teachers of the colored school." ${ }^{35}$

Racial bias could be compounded by class and gender bias. Swedetown School remained totally segregated and private for six years, and only men were appointed to the superintendent's position. Although four of Buxton's African American women teachers had college degrees, the CCC did not select any of them to be the town's school superintendent. As historian Linda Perkins notes, African American college women "may have outnumbered black men in the college population, but they were not in major decision making positions; black men controlled [predominantly] black institutions." ${ }^{36}$

M. J. Gilliam, a graduate of Cornell University, was Buxton's first superintendent. Gilliam, a white male, held the position from 1905 to 1907. Some residents believed that a college graduate should hold the position, especially because Buxton had a short-lived high school. ${ }^{37}$ Although some sources contend that Gilliam left Buxton when the high school burned down, three former residents suggest that Gilliam was fired for mistreating one of the daughters of Buxton's most prominent black

189-90, 208-27; David S. Cecelski, Along Freedom Road: Hyde County, North Carolina and the Fate of Black Schools in the South (Chapel Hill, NC, 1997), 7-8, 124-25.

35. Quoted in Schwieder, Hraba, and Schwieder, Buxton, 111, 232 nn. 43 and 44. 36. Jeanne Noble, "The Education of Black Women in the Twentieth Century," in Women and Education in American History, ed. John Mack Fargher and Florence Howe (New York, 1998), 90-91. See also Linda Perkins, "The Education of Black Women in the Nineteenth Century," ibid., 79-80; Lucy D. Slowe, "Higher Education of Negro Women," Journal of Negro Education 2 (1933), 357.

37. Biennial Report of the Superintendent of Public Instruction (1906), 286; Bystander, 11/24/1905, 4/13/1906. 
resident, Hobe Armstrong. All three recalled that Gilliam had a policy of locking the doors to encourage students to get to school on time. On an occasion when Armstrong's biracial children were late for school, Gilliam refused to unlock the doors. To retaliate, Armstrong had Gilliam fired. ${ }^{38}$ After Gilliam's departure, the CCC selected A. J. Hicks, a college-educated African American, for the position. ${ }^{39}$ Perhaps the CCC's appointment served as an act of reconciliation or came in response to protests by black Buxtonites. If the CCC fired Gilliam at Armstrong's request, perhaps Armstrong's seniority and tenure meant more to white CCC officials than Gilliam's whiteness. ${ }^{40}$

In most years, the CCC and the county school board employed an equal number of black and white teachers in an effort to perpetuate the town's relative equality. Buxton schools employed approximately 10 to 12 teachers, at least 6 of them African American during any given year. ${ }^{41}$ Minnie London had taught in the schools operated by the CCC since 1891. London not only taught in Muchakinock, Buxton, and Haydock; she also served as principal of one of Buxton's grade schools. In her

38. Gertrude Stokes, Agnes Walker, and Nina Bragg, interview with Dorothy and Elmer Schwieder, 6/15/1981, 633.

39. The 1920 United States Federal Census lists A. J. Hicks as a resident of Bluff Creek Township, Monroe County, Iowa. He was 39 years old, born in Ohio, and is possibly the Ananias J. Hicks who was a student a Wilberforce University in Ohio in 1900. See 1920 United States Federal Census, Roll T625-503, 9A; 1900 United States Federal Census, Roll T623 1272, 1B; and Jeremy J. Brigham and Robert Wright Sr., "Civil Rights Organizations in Iowa," in Outside In, 326.

40. Sources do not reveal whether any of Buxton's African American women teachers sought the superintendency. With regard to tenure, Minnie London was possibly best suited for the position, but she did not have a college degree, as Gilliam and Hicks did. Contrary to the claim that Minnie London graduated from the University of Iowa, no university records, catalogs, registrar records, London's memoirs, or the Schwieder interview with her daughter Vaeletta London Fields suggest that London ever attended the University of Iowa. See both sides of the argument in Susan Fletcher, "Minnie London," Goldfinch 16 (Summer 1995), 8. See also Richard M. Breaux, "'We Decided What We Wanted and Went About Getting It': A History of African American Women at the University of Iowa, 1907-1949" (paper presented at Midwest History of Education Society, Chicago, October 1999).

41. Biennial Report of the Superintendent of Public Instruction (1904), 36; ibid. (1906), 286; ibid. (1908), 338; ibid. (1910), 211; ibid. (1912), 238-39; ibid. (1914), 302-3; ibid. (1916), 164-65; ibid. (1918), 308-9; ibid. (1920), 332-33; Schwieder, Hraba, and Schwieder, Buxton, 126-29. 
memoirs, London remembered that some 13 African American teachers taught school in Buxton during the town's existence. ${ }^{42}$ Some of them stayed in Buxton for a year or two and then found work in other states. Nell Leftridge moved on to take a job at Bishop College in Texas, and Nora Harris moved to New Jersey to teach. ${ }^{43}$ Others, such as Minnie London, Grace Harris Potter, and Georgia Blackburn, worked for the CCC for more than five years. Whether teachers remained in Buxton for one or five years, the community provided a rare opportunity for Buxton's African American teachers to challenge the racial and class prejudices of its black and white students. Consequently, Buxton's school-age residents learned what it took for the races to have a relatively equal and interdependent relationship.

African American teachers in Buxton possessed the credentials and demonstrated the teaching skills to challenge white stereotypes concerning African American and women's intellectual inferiority to white men. Some African American teachers in Buxton had earned credentials that greatly exceeded the minimum state requirements. During much of Buxton's existence, all teachers in Iowa were required by law to have earned a teaching certificate by passing an examination administered by the State Board of Educational Examiners after graduating from high school and securing a strong teaching recommendation. ${ }^{44}$

Colleges and universities throughout the state also granted teaching certificates along with bachelor's degrees. Georgia Blackburn, a longtime teacher who later became principal of Buxton School \#1, had graduated in 1902 from Penn College in Oskaloosa, Iowa. A college administrator described Blackburn as "a student of fair ability" who "since graduation has been teaching and has met excellent success." ${ }^{45}$ Ina Lafayette also

42. London, "As I Remember," 3. Those teachers included Eliza Bates, Beatrice Terrell, Georgia Blackburn, Grace Harris Potter, Nora Harris, and Lola Hart Reeves.

43. Bystander, 11/23/1917; Bessie Lewis, interview with Joseph Hraba, 1/17/ 1981, 916, 940.

44. Herbert Cook, The Administrative Functions of the Department of Public Instruction in Iowa (Iowa City, 1929), 59.

45. Unknown administrator quoted in W. E. B. Du Bois, "The College-Bred Negro American," Proceedings of the Fifteenth Annual Conference for the Study of Negro Problems (Atlanta, 1910), 30. Du Bois mentions Blackburn as being one of 
served as a teacher and principal in Buxton School \#1 in 1910 after graduating that year from Penn College. ${ }^{46}$ Eliza Bates, another African American teacher, graduated from Oskaloosa High School and Western College in Macon, Missouri. ${ }^{47}$ Nell Leftridge graduated from the University of Kansas before coming to Buxton to teach; and Nora Harris and Grace Harris Potter graduated from Iowa Wesleyan College in 1906 and 1912 respectively. ${ }^{48}$ Murda Beason, also a teacher in Buxton, was one of two African American women to graduate from Iowa State Teachers College in 1916. ${ }^{49}$ Other Buxton teachers, such as Beatrice Terrell, had only completed high school in other Iowa towns. ${ }^{50}$ Still, these teachers' credentials not only demonstrate that Buxton students probably received an education equal to that of other students in Iowa; they also showed residents of Buxton at the time that African American women and men possessed the intellectual ability to compete with European Americans, thus cementing the idea of racial equality in the town.

African American teachers in Buxton sought out opportunities to develop their teaching and administrative skills. They attended teaching methods workshops and classes in various towns throughout the state. On several occasions, teachers such as Minnie London, Georgia Blackburn, and Mayme Findley attended mandatory refresher normal courses and renewed their

the alumnae teaching in Buxton although not by name. Ibid., 31. Blackburn was principal and teacher in Buxton School \#1 from 1911 to 1917. For more on Blackburn's college years, see Penn College Aurora yearbook (1902), 51-52, 176, William Penn College Archives, Oskaloosa, Iowa. Who's Who Among Pennites (Oskaloosa, 1927), 18, lists Georgia Blackburn as a teacher in Chicago.

46. Bystander, 11/4/1910, 3/8/1912; Penn College Aurora yearbook (1910), 6; Penn College Bulletin (1909-10), 50, William Penn College Archives. Lafayette taught in Buxton for one year. Who's Who Among Pennites (Oskaloosa, 1927), 31, lists Ina Lafayette as a resident of Saskatchewan, Canada.

47. Bystander, $1 / 5 / 1906$.

48. Bystander, 6/16/1911; C. J. Kennedy and Lilian Kendig Rogers, History and Alumni Record of Iowa Wesleyan College, 1842-1942 (Iowa City, 1942), 165, 173.

49. “Our Graduates," Crisis, July 1916, 123. Murda Beason attended Iowa State Teachers College with Vivian Smith, but graduated five months earlier. Smith appears in cap and gown on the cover of the Summer 1995 Goldfinch.

50. Bystander, 11/17/1905. Terrell was from a middle-class African American family. Two of her sisters worked at the Monroe Mercantile Company store. 
certificates in nearby Albia. ${ }^{51}$ Buxton's African American teachers had attended the county-directed normal training course since 1906, although the Iowa General Assembly did not mandate that county normal institutes operate under the direction of the state superintendent until $1911 .{ }^{52}$ Teachers such as Gertrude Lucas attended summer courses at Drake University to keep up on current approaches to teaching. ${ }^{53}$ African American educators living inside and outside the state with family connections to Iowa met to establish their own workshops and professional networks. ${ }^{54}$

Several of Buxton's African American teachers, including Minnie London, Eliza Bates, Georgia Blackburn, and Mayme Findley, were active members of the Iowa State Teachers Association. ${ }^{55}$ In his work on rural Iowa schools, David Reynolds argues that the name Iowa State Teachers Association was a misnomer because the organization "was controlled by school administrators, principally the 'college men' in the state's colleges and universities and the superintendents of schools in the state's cities and larger towns." ${ }^{56}$ That centralization of control, however, may have enabled Buxton's black teachers to become members of the association. If power had been in the hands of a more localized or grassroots leadership, black teachers might have been barred from the association. Despite teachers' general

51. Bystander, 4/13/1906, 3/29/1912, 11/27/1914. During 1914, all six African American teachers who taught in Buxton attended the two-day session in Albia.

52. Laws of Iowa (1911), chap. 131; Cook, Administrative Functions of the DPI, 55; Bystander, 4/13/1906. For more on the development and control of normal schools and the teacher certification process in Iowa, see Cook, Administrative Functions of the DPI, 55-66 and 68-70.

53. Bystander, 6/21/1912, 6/28/1912.

54. Bystander, 9/4/1914.

55. Bystander, 11/4/1911; Proceedings of the Fifty-sixth Annual Session of the Iowa State Teachers Association (1910), 127, 139, 152, 164. Black Buxton teachers C. W. Rodgers and Murda Beason also attended the 1910 ISTA meeting. Only Minnie London appears to have renewed her membership the following year. Proceedings of the Fifty-seventh Annual Session of the Iowa State Teachers Association (1911), 190. As early as 1905, M. J. Gilliam (white) was a member of the ISTA. Proceedings of the Fifty-first Annual Session of the Iowa State Teachers Association (1905), 227.

56. David R. Reynolds, There Goes the Neighborhood: Rural School Consolidation at the Grass Roots in Early Twentieth-Century Iowa (Iowa City, 1999), 63. 
lack of power and control in the association, Buxton teachers probably used its conferences to establish pipelines through which they could send their most promising students on to high schools throughout the state.

Of particular interest to London and her cohorts at the 1911 Iowa State Teachers Association meeting was the speech given by Booker T. Washington, who despite his most famous pronouncements, found that Buxton's schools were social institutions where blacks and whites could work toward "mutual progress." ${ }^{57}$ Principal of Tuskegee Institute and the most influential African American educator in the first 15 years of the twentieth century, Washington was often consulted on matters concerning African American work, political participation, and education in the North and South. Just as he had in his previous talks in Iowa, Washington suggested that African Americans could benefit more from the southern economy than from the northern one. ${ }^{58}$ In fact, in several public speeches, Washington urged northern whites to discourage African American migration to the North.

Washington chose this particular occasion to deviate slightly from his more widely known mantra, acknowledging that "in certain industries, as in mining, it is possible for the Negro to succeed in a state like Iowa," an obvious reference to Buxton. Washington had, in fact, visited the CCC town of Muchakinock in 1899 and had been impressed by the town's social and economic efficiency. ${ }^{59}$ But, he continued, "in a larger sense, the colored people are best adapted to agricultural life, and the average southern state furnishes them with a greater opportunity

57. Booker T. Washington, "Education and Its Influence on Solutions of the Race Problem," in Proceedings of the Fifty-seventh Annual Session of the Iowa State Teachers Association (1911), 7; Bystander, 11/10/1911.

58. Bystander, 2/24/1911. The next month Washington spoke at the North West State Teachers Association Conference in Sioux City (March 10); at Iowa State College in Ames (March 11); and at the Iowa State Teachers College in Cedar Falls (March 14). Washington had recruited George Washington Carver from Iowa State College and Frank J. Armstrong from Cornell College.

59. Booker T. Washington to Charles A. Kent, 10/22/1898; Booker T. Washington to Charles A. Kent, 10/27/1898; Booker T. Washington to Charles A. Kent, 2/21/1899, all in William Penn College Library Archives; Bystander, 2/3/1899, 2/10/1899; Schwieder, Hraba, and Schwieder, Buxton, 31. 
than Iowa as land is one-quarter as cheap in the South." ${ }^{60} \mathrm{Al}-$ though he clearly did not advocate a mass African American migration, Washington conceded that African Americans found better opportunities in Buxton than in the northeastern states. ${ }^{61}$ Perhaps Buxton teachers attending the 1911 conference took Washington's point about mining towns as an affirmation of their efforts to provide Buxton children with one of the best educational opportunities for African Americans in the state.

OVERLOOKED PORTIONS of the interviews conducted in the 1980s with former Buxton residents offer information on the organization of Buxton's schools and the day-to-day activities that took place within them. Classes met eight months out of the year for approximately six hours each day. Students walked to school. Occasionally, deep snow prevented students from walking to school and classes were cancelled. One spring a tornado swept through the outskirts of town and schools were dismissed. Teachers divided their classes by grades. Each teacher taught two grades; there was no kindergarten. According to Gertrude Stokes, who attended Fifth Street School through the eighth grade, children in grades 1-4 attended classes downstairs while children in grades 5-8 were upstairs. Sources do not reveal how often grade reports or report cards were issued; however, Herman Brooks recalled that students received "Ps" for poor or "Fs" for fair. ${ }^{62}$

60. Washington, quoted in Des Moines Register and Leader, 11/12/1911. Washington's wife visited Buxton and Des Moines in 1914 as a guest of the Iowa Federation of Colored Women's Clubs. Bystander, 11/27/1914 and 12/11/1914.

61. Washington, quoted in Des Moines Register and Leader, 11/12/1911. Washington had worked in West Virginia coal mines before he enrolled at Hampton Institute. See Booker T. Washington, "The Story of My Life and Work" and "Up from Slavery," reprinted in Louis Harlan and John Blassingame, ed., The Booker T. Washington Papers (Urbana, IL, 1972), 1:17, 233, 236; Louis R. Harlan, Booker T. Washington: The Making of a Black Leader, 1856-1901 (New York, 1972), 48. Washington was influential among educators in black towns, according to Hamilton, Black Towns and Profit, 56-57, 126-27, 145.

62. Herman Brooks, interview with Dorothy and Elmer Schwieder, 7/30/1981, 475; Minnie B. London, “As I Remember," (1940), 2, copy of typescript, State Historical Society of Iowa, Iowa City; Mike Onder, interview with Joseph Hraba, 6/23/1981, 860; Adolph Larson, interview with Joseph Hraba, 7/23/ 1981, 971; Gertrude Stokes, interview, 628; Harvey Lewis, interview with Joseph Hraba, 12/29/1980, 1293. 
During recess and lunch, black and white students regularly ate and played together, in sex-segregated rather than racially segregated groups. Lara Wardelin, Hucey Hart, and Charles Lenger all remembered that black and white children played together at school, and on occasion outside school. They did segregate by gender, however. On the schoolyard, boys played baseball and marbles, while girls played hopscotch and jump rope. ${ }^{63}$ It is unclear whether sex segregation was imposed by regulation or by choice. Inside the classroom and in most other school activities, however, even this division seems to have disappeared.

Unlike in the South and portions of the North, the racial makeup of Buxton's staff and student body played little or no role in the county's or CCC's allotment of resources to Buxton's schools. All of the schools in Buxton likely had equal resources and similar structure. Schools took the name of the street or the part of the town in which they were located. All were fourroom, two-story structures with two rooms upstairs and two rooms downstairs. There was no auditorium or central meeting room. Large events, such as assemblies, were held in the YMCA because the schools had no room large enough to hold all students at once.

Buxton's schools were crowded. ${ }^{64}$ Several accounts in the Bystander noted that the classrooms in Buxton were filled to capacity "especially at the lower grades." Alex and Agnes Erickson, who attended school in Swedetown, remembered that there were about 50 students per class. In 1917 Dr. F. F. Walker visited Buxton and suggested the development of a parentteacher association because the schools were "overcrowded"

63. Lara Wardelin, interview with Dorothy and Elmer Schwieder, 7/8/1981, 345; Hucey Hart, interview with Dorothy and Elmer Schwieder, 11/1/1980, 270; Charles Lenger, interview, 539-40. See also Douglas, Jim Crow Moves North, 145.

64 . According to the state superintendent's biennial reports, an average of 625 total students attended school in Buxton, about 225 students per school. Averaged from the Biennial Report of the Superintendent of Public Instruction (1904), 36; ibid. (1906), 286; ibid. (1908), 338; ibid. (1910), 211; ibid. (1912), 238-39; ibid. (1914), 302-3; ibid. (1916), 164-65; ibid. (1918), 308-9; ibid. (1920), 332-33. Only the 1911-12 school report gives a school-by-school breakdown. The schools where Georgia Blackburn, Minnie London, and Verena Drohan were principals enrolled 223, 243, and 210 students respectively. Biennial Report of the Superintendent of Public Instruction (1912), 238-39. 
and needed more teachers. A report by a joint committee of the United Mine Workers, the Iowa Coal Operators Association, and personnel chosen by the Superintendent of Public Instruction, published in the United Mine Workers Journal, echoed Walker's concerns. The report declared that schools in Buxton and other Iowa mining towns "were overcrowded and badly in need of additional teachers, more classrooms, and better textbooks." Similar reports led to legislation that increased state support to camp schools and helped to relieve the burden of unequal tax revenues. ${ }^{65}$

Despite their overcrowded classrooms, black and white teachers served as important points of contact for parents to remain informed about their students' progress and development. This shaped parents' perception that black and white teachers cared equally about their students. Several former students remembered that teachers constantly kept parents abreast of what was going on in the classroom. Jacob Brown, who attended Eleventh Street School, remembered that "if you didn't learn, your teacher went to your parents and from there on in you would learn something, because if you did not learn, the teacher had a right to see that you did." Marjorie Brown's parents would scold her if she couldn't tell them what she had learned in school. On the other hand, Elmer Buford and Harold Reasby recalled that their parents did not seem very interested in "the happenings" of school, although the teachers kept parents notified of their children's progress. ${ }^{66}$ Lola Reeves, an African American teacher, remembered that some children brought

65. Bystander, 9/22/1911, 9/14/1917; Agnes and Alex Erickson, interview with Dorothy and Elmer Schwieder, 8/15/1980, 787. State expenditures for camp schools rose from $\$ 50,000$ in July 1919 to $\$ 100,000$ in 1921. An additional $\$ 10,000$ was added for an emergency fund in 1927. Laws of Iowa (1919), chap. 373; ibid. (1921), chap. 295; ibid. (1925), chaps. 218, 233; ibid. (1927), chaps. 275, 259; Cook, Administrative Functions of the DPI, 65-66; Biennial Report of the Superintendent of Public Instruction (1920), 66; ibid. (1924), 5; Dorothy Schwieder, Black Diamonds: Life and Work in Iowa's Coal Mining Communities, 1895-1925 (Ames, 1983), 146-47; and Schwieder, Hraba, and Schwieder, Buxton, 81.

66. Jacob Brown, interview, 320; Marjorie Brown, interview with Dorothy and Elmer Schwieder, 8/19 and 8/20/1980, 53 and 57 (also quoted in Schwieder, Hraba, and Schwieder, Buxton, 144); Elmer Buford, interview with Dorothy and Elmer Schwieder, 6/30/1980, 1191; Harold Reasby, interview with Dorothy and Elmer Schwieder, 8/19/1980, 741. 
punishments upon themselves, and "parents would come to the school because the student did not tell the entire story." 67 The depth of parents' concerns about their children's education varied from home to home; however, the value that teachers placed on doing their job is clear. Teachers believed that parents, regardless of race, should be informed about their students' intellectual growth.

Students who did not complete their work or stepped out of line with a teacher were often punished or received beatings. Such discipline was apparently handed out equally, although black teachers seem to have physically punished only black students and white teachers physically reprimanded only white students. Earl Smith, a white student who attended the Eleventh Street and East Swedetown schools, remembered:

When we went to class we stayed in our own seats[.] See it was just the two classes, half of us there seventh and the other half eighth. Everybody took a book and you read a whole paragraph. And then the one in back of you would read a paragraph and just went that way clear through the school. Then you shut your book and buddy you'd better be paying attention to what everybody read. If he [Mr. Baker] asked you a question and you didn't know it, he'd flog some of them big old kids. ${ }^{68}$

Teachers in Buxton challenged their students to master the broad range of subjects necessary for pupils to move to the next grade. Charles Lenger remembered that Georgia Blackburn "was an excellent teacher that I recall and we had different programs we had to do and we were taught things as our grade." ${ }^{69}$ Another former student, Elmer Buford, who attended Fifth Street School, recalled,

Buddy, you learnt there you'd better believe it. Here [in Des Moines] they pass you on just to get you out of one grade into another. Down there [in Buxton] they didn't do that. You stayed there until the seat got too small for you to sit in. And you could believe it.

67. Lola Reeves, interview, 1601.

68. Earl Smith, interview, 1139.

69. Charles Lenger, interview with Joseph Hraba, 7/22/1981, 538. Students said the same thing about Grace Harris Potter. See Jeanette Adams, interview with Joseph Hraba, 6/21/1980, 37. 
Mrs. London, Miss Dimitri, Miss Golds, Miss Baxter. Buddy let me tell you, you stayed there until you learned! They didn't pass you just because you got too big for the seat. They set you on the bench, and you still stayed in the same class. But when you come out of there, you knowed your [stuff]. If you was in fifth grade, you knowed everything that you could learn in the fifth grade. ${ }^{70}$

Only a few sources reveal the specific content of the curriculum in Buxton's schools. Former students and teachers who mentioned the curriculum usually talked about learning math, spelling, reading, and writing. Charles Taylor, who attended Fifth Street School, remembered, "The biggest thing that they taught [were] reading, writing, and arithmetic and a lot of history, geography, a lot of religion that's about [all]." Earl Smith remembered that, in addition to the three Rs, students learned "hygiene, civil government, history, [and] geography." And on one occasion, Minnie London used a traumatic event to teach science and nature. After a tornado stormed through the outskirts of town, London wrote, "we went out for a lesson in nature study." 71 In general, the curriculum was apparently similar to that taught in other Iowa common schools.

Neither the racial demographics of Buxton's students nor the presence of black teachers influenced the formal curriculum enough to include African American history or literature. ${ }^{72}$ Even if teachers did not integrate African American history into the curriculum, Charles Taylor noted that his grandparents

70. Elmer Buford, interview, 1190-91.

71. Charles Taylor, interview; Earl Smith, interview, 1140; and Minnie London, "As I Remember," 2. See also Lola Hart Reeves, interview, 1601.

72. Earl Smith, interview, 1140. Teachers in Buxton might have used the Bystander and other black newspapers as teaching tools. In the Educational Meeting of the Iowa Federation of Colored Women's Clubs, members discussed the educational value of newspapers and periodicals. Bystander, 5/19/1911. Buxton members might have passed that on to local teachers. For more on the use of black newspapers and speakers, see Mabee, Black Education in New York State, 152-53; and Vincent P. Franklin, The Education of Black Philadelphia: The Social and Educational History of a Minority Community, 1900-1950 (Philadelphia, 1979), 97-98. In racially segregated schools in southern West Virginia's coal fields, African American teachers were free to teach whatever they wished as long as they avoided any discussion of labor policies or practices. Teachers in West Virginia took advantage of that opportunity to teach African American history and literature. Corbin, Life, Work, and Rebellion, 72. 
taught him and his siblings about African American history. Taylor stressed that his grandparents, who had been slaves, told them about their and others' experiences during slavery. ${ }^{73}$

Manual training and vocational education also appear to have been absent from the curriculum. On occasion, representatives from Tuskegee Institute and Piney Woods Country Life School in Mississippi visited to recruit students, and individual townspeople offered manual training classes through the YMCA. ${ }^{74}$ But children learned much of what they came to know about work from parents, relatives, and employers. For example, middle- and working-class girls of both races learned to cook, clean, and care for children from female family members. And miners often took their sons, nephews, and other younger relatives to the mines when they turned 14 to learn the ins and outs of coal mining. Several Buxton residents recalled assisting their fathers in the mines until they were old enough to work with little supervision. Working-class male children were more likely to leave school by age 14 to work in the mines. If families needed to supplement their income, both girls and boys left school to work in town. ${ }^{75}$

73. Charles Taylor, interview. Black Buxtonites were not the only people to educate their young people about a past that reflected the unique experiences of their racial or ethnic group: older white Buxtonites imparted similar knowledge to their children. Among Buxton's Swedish population, teachers held summer school where instruction was in Swedish only. Some Swedish students referred to school during the regular school year as English school. Adolph Larson, interview with Joseph Hraba, 7/23/1981, 970-71; Agnes and Alex Erickson, interview, 764. Larson remembers Swedish school being mostly catechism. According to the Eriksons, interview, 787, the Swedetown School was founded as a private school. For more on Americanization and parent resistance to assimilationist pedagogy in immigrant education, see David B. Tyack, The One Best System: A History of Urban Education (Cambridge, 1974), 229-54.

74. Bystander, 2/2/1906, 12/17/1909, 4/8/1910, 7/29/1910, 6/30/1911. The larger of the two YMCAs in Buxton served African Americans predominantly. Almost every Buxton report in the Bystander took note of the educational activities held there. For more on the impact of the YMCA on African American education, see Jesse Moorland, "The Young Men's Christian Association among Negroes," Journal of Negro History 9 (1924), 354-62; and Franklin, Education of Black Philadelphia. Moorland visited Buxton's YMCA in October 1912. Bystander, 10/11/1912.

75. Schwieder, Hraba, and Schwieder, Buxton, 67, 121-23, 132-35, 141-42. 
On the other hand, school subjects such as English and math prepared girls and boys to work as sales clerks, stock workers, and small business owners. The CCC's board members also thought that the presence of educated miners reduced the number of accidents in the mines. Some students learned trades through YMCA classes in millinery, furniture building and repair, and carpentry. Other students, such as Edward Carter and William Brown Jr., who became members of Buxton's emerging black middle class, worked in the mines or at the Monroe Mercantile Company during the summers to pay for advanced education outside Buxton. Some African Americans, such as W. H. and A. E. London, took advantage of the savings plan initiated by the CCC superintendent and saved enough money and acquired enough property to leave the mines and start businesses. The presence of black middle-class youngsters in the mines, however, was rare. Black workingclass Buxtonites were much more likely to work in the mines. ${ }^{76}$

Boys from working-class families rarely stayed in school beyond age 14. In the early twentieth century, many parents saw little utility in educating their sons beyond the primary levels. Boys often went to work to supplement the family income. Girls who attended the upper grades and secondary school added to the family income by obtaining a teaching license. ${ }^{77}$ Harold Reasby remembered that parents were generally more interested in their children becoming old enough to work than in furthering their education. In his home, family members only discussed the value of education in relation to work and the immediate needs of the household. When the children became a certain age, work was more important than school. ${ }^{78}$ Parents' attitudes concerning the relationship between school and work possibly account for the low number of students who completed the eighth grade.

76. Edward A. Carter, MD, to Prof. Paul S. Pierce [sic], 12/7/1909, Edward A. Carter Papers, State Historical Society of Iowa, Des Moines; Ben C. Buxton, letter reprinted in Bystander, 5/4/1906.

77. David Tyack and Elisabeth Hansot, Learning Together: A History of Coeducation in American Public Schools (New Haven, CT, 1990), 135-38.

78. Harold Reasby, interview, 741. Adolph Larson quit school to go to work for the company store. Larson, interview, 972. 
Buxton's well-educated black teachers helped students meet state eighth-grade graduation requirements. To graduate, Buxton students, like all other students in Iowa, were required to pass the state eighth-grade examination, which was administered at least once a year. Students could retake the exam if they failed. In 1914 Buxton's teachers administered tests in February, May, and August. After students completed the exam, teachers sealed and mailed the tests to Des Moines to be scored. Those who passed were determined eligible for high school. According to the Bystander, Minnie London's entire eighth-grade class passed the state examination in 1911. In 1914, 38 students took the exam, and 18 students graduated with eighth-grade diplomas. On average, approximately 9 students per year graduated from Buxton's eighth grade. In the reports that enumerated graduates by sex, a total of 61 girls and 23 boys completed the eighth grade between 1912 and $1918 .^{79}$

All of Buxton's schools combined their respective graduations into one ceremony, thereby affirming the spirit of interracial and community harmony. Although no more than 18 students graduated in any year, the schools had to reserve the auditorium in the Buxton YMCA because no room in the schools was large enough. Commencements included speakers, concerts, and a host of other events. ${ }^{80}$ In her memoirs, Minnie London recorded the typical end-of-the-school-year activities: "The closing exercises of the school, which marked the graduation of eighth grade pupils was always looked upon with great anticipation, and at such times the County Superintendent was usually present. To the YMCA we went and the plays, pageants and drills were always greeted with cheers and enthusiasm." ${ }^{81}$

79. Copies of lists of students who passed the eighth-grade examination, in "School Records File," Filing Cabinet, Microfilm Room, Albia Public Library, Albia, Iowa (these might be the lost school records mentioned in Walter and Mildred Gardner, interview with Dorothy and Elmer Schwieder, 6/4/1981, 602); Bystander, 4/14/1911, 5/19/1911; Biennial Report of the Superintendent of Public Instruction (1904), 36; ibid. (1906), 286; ibid. (1908), 338; ibid. (1910), 211; ibid. (1912), 238-39; ibid. (1914), 302-3; ibid. (1916), 164-65; ibid. (1918), 308-9; ibid. (1920), 332-33.

80. Vaeletta London, interview with Dorothy and Elmer Schwieder, 437; Bystander, 5/10/1912.

81. London, “As I Remember,” 2; Bystander, 5/25/1917. 
Several accounts in the Bystander noted that a "large and appreciative audience" witnessed the eighth-grade commencement exercises. $^{82}$ Teachers, parents, and students from the town's predominantly white school and two predominantly blacks schools worked together to make these occasions pleasant for the children and their families.

Black teachers helped black Buxtonites determine whether high school or college was within reach for black children. Some working- and middle-class black Buxtonites sent their children to other Iowa towns to attend high school, and some sent their children on to college. The CCC completed a high school in Buxton in 1906; other coal-mining towns in Iowa, and coal towns in other states, tended not to have high schools. ${ }^{83}$ In the only year that Buxton High School was open, 36 students enrolled. By 1907, the high school in Buxton had burned down, and CCC board members never constructed another school. ${ }^{84}$

In 1911 the Iowa General Assembly passed a free-tuition law that required all towns with no high school to pay their students' tuition to attend any school in the state. The extent to which Buxton's black families took advantage of that law remains unclear. Long before the passage of the free-tuition law, black and white middle-class Buxtonites had developed a tradition of sending their children to other Iowa towns for high school. For example, Edward Carter's parents, who lived in Muchakinock and later in Buxton, sent him to high school in Oskaloosa, Iowa, and later to the University of Iowa, where he received a B.A. and an M.D. (1900-1907). He subsequently worked as the CCC's only African American doctor. Eva Bates graduated from Oskaloosa High School in 1903, and Vaeletta and Hubert London attended high school in Des Moines and Oskaloosa, respectively. Vaeletta London remembered that while attending high school, she lived with her aunt and later with a woman recommended to her family by the principal of the high school. Vaeletta and Hubert London went on to graduate from the

82. Bystander, 5/19/1911, 5/10/1912, 5/25/1917; Jacob Brown, interview, 320.

83. Corbin, Life, Work, and Rebellion, 72, notes that "high schools were conspicuously absent from the coal fields" in West Virginia.

84. Biennial Report of the Superintendent of Public Instruction (1906), 286; Reynolds, There Goes the Neighborhood, 72-73. 
University of Iowa. The Carter and London families had been with the CCC since the late 1880s and early 1890s; their longevity with the company provided them with the resources to build a strong family kinship network and a firm economic foundation for future generations. Both families used those resources to educate their children through the college level. ${ }^{85}$

INTERRACIAL SCHOOLS and African American teachers proved to be crucial forces in shaping blacks' and whites' fond memories of Buxton. Both black and white former residents remember that schools were essential to maintaining the town's "racial harmony." The very presence of African American teachers challenged mainstream stereotypes about blacks' and women's intellectual inferiority, and stretched the commonly conscribed boundaries of race and gender through their involvement with formal educational organizations and institutions. Despite the continuous expansion of Jim Crow throughout the country and the rise of violence against blacks in the years immediately following World War I, Buxton remained a place where manifestations of racism and discrimination were minor relative to places such as Des Moines, which would not see a black teacher until 1946, and Waterloo, where officials barred African Americans from teaching until 1952. ${ }^{86}$

85. Edward A. Carter, M.D., to Prof. Paul S. Pierce [sic], 12/7/1909, Edward A. Carter Papers, State Historical Society of Iowa, Des Moines; Schwieder, Hraba, and Schwieder, Buxton, 143-45; Vaeletta London, interview, 423. Cleo Cary and Percy Smith attended Albia High School. Bystander, 1/19/1912. Like Vaeletta and Hubert London, Ruth Southall and Mary Perkins attended the University of Iowa. London and Southall's college roommate, Helen Lucas, had family in Buxton as well. Bystander, 6/21/1912, 6/28/1912, 1/9/1914. William A. Brown Jr., Lucy Rhodes, Orvel Carter, Louis Garland, and Earl Watson attended Western College in Missouri. Bystander, 12/30/1910, 5/26/ 1911, 5/31/1912. Frank Perkins attended Fisk University, and his brother George attended Lincoln University in Missouri. Bystander, 12/30/1910, 6/28/1912. See also Schwieder, Hraba, and Schwieder, Buxton, 145.

86. Bergmann, Negro in Iowa, 87-88. 